\title{
MINTAN ACTIVITIES
}

FIRST DIVI3ION - The uranlum prospect of Soutleastern M1ning and Exploration Co. near flliam Fenry Bay an the Lym Canal is now belag drilled. The company obtalned a DMEA asalstance contract and the Boyles Brothers Drilling Colipany is dolng the arllling. Equipment and supplies were lifted to the property at 1800 feet elevation by hellcopter.

Kendrtck Bay Miniag Company (Climax Molybdenum Co. oubsidiary) has 1ts truck roed nearly completed to its urantin property ou Bokan Mountain. The road w1ll be $1-3 / 4 \mathrm{mlles}$ long and will cross a ridge at about 1250 feet elevation enroute, glving the road an average grade of $15 \%$ from Kendrick Bay to the rldge top. Nining by open pit and trucking the ore to the beech is expected to start in mia-July. Shlpment will be to the new uranium mill near Spolsane, Hashington. thise ourmer.

Testing of the Klukwan Iron deposit by U. S. Steel is in progress again

Exploratory drifting on the 200-foot level is going ahead at the Admiralty-Alakk nlckel property at Funter Boy. A contractor from Tacoma, Mr. Spencer, is advancing the heading as rapidiy as posblbie. Espertenced manpower IB a problem.

SECOND DIVISION - Three dredges of the USSR\&N Company wiIl work in the Name aree this year for the flrst time since 1953 when one of the dredges capsized.

FOURIE DIVISION - The USSRRM Compeny is operating five dredges in the Fairbanks erea this season. They are on CrIpple, Engtneer, Dome, and Pedro Creeks and at Gold B1ll. Gold Eill is neerly worked out and it 18 planned to move the dredge from there to sheep Creek this winter. In the "Hog" RIver area, it will be the first full dredging season for the dredge that was purchesed and moved there from Livengood tro years ago.

\section{OII NEWS}

A news Item reports that the Canadian court case against Alsaka Yukon Refiners and. DLstributor has been settled, and it 1 B asoumed that their plano for a reflnery at Halnes will again move abead. Construction of a tank farm and marketing facllities at Whitehorse has been completed.

Globel Enterprises, Inc. Is moving Into the Kateel River area with drilling and other equipment for selsmlc exploration. The base camp will be on the Yukan River 25 miles southwest of the confluence w1th the Koyukuk. Tentative 
plans for well drilling include shipping the drill rigs tato Norton Sound before the freeze-up this fall, then hauling overland by cat trains. It is reported that the Paul G. Benedum family of Plttsburgh is financing the project.

IegIslation hes been Introduced in Congress to proslde Federal authority for leasing ofl lands beneath inland (nontidal) Lavigaile waters. At present there 18 no such authorfty, and oll or ges could be drawn from weter-covered areas by bordering leaseholders with the resultant ioss of future revenue to Alaske. Under the proposed b1ll, 37-1/2\% of the revenue from such leases would go to Aleske for schools and roeds, $52-1 / 2 \%$ for disposition by the Leglslature, and $10 \%$ to the Federal Treasury. The House Torritonles subcomittee has approved the 0112 , and it also bas the support of the Departnlent of the Interior. A second bill dealing with lando beneath tidal and coastal waters $1 \mathrm{~s}$ expected.

\section{ASSESSMENT WORK RFMINDER}

The flrst day of July at noon $1 \mathrm{~s}$ otill the deadline for the completion of assesment work for the assesgment work yetr of $1950-5 \%$. Also we algat again call attention to the new Territorlal Law requiring the filing of assessment work affidavits within $01 \mathrm{x}$ months after the end of the assessment year if a claim holder wlshes to continue legally holding his claim. This new law was explained in detail in our special legislative TDM Eulletin dated April 25. If there are question on this, we will be gled to answer them to the best of our abllity.

\section{NEW USGS MAP}

A new map showing structural detalls of the western part of the Prince W1lliam Sound area has been releaged to open file by the U. S. Geological Survey. It shows Inear features interpreted as probable faults, jolints, and shear zones. These feetures were interpreted entlrely from aerlal photographs. Locations of mines and prospects heve also been plotted on the map. The t1tle is "Map of a part of Prince William Sound area, Alaska, sàowing linear \&ealogic features as seen on eeriel photographs." It may be seen in the USGS offices at Jumeau, Anchorage, or College, and in the TDM office at Juneau. The USGS at 4 Homewood Place, Menlo Park, California will make coples of tine uap at the expense of the person requesting them.

\section{HET,ICOPTER SERVICE}

Avallable helicopter service in southeastern Alaska has increased. In addition to the Alaska Coastal Alrlines, there 1 s now the Juneau Copter Service, also based in Juneau, and Dean Johnson, Inc., based in Ketchikan. All three compantes have Hiller helfcopters and wlll operate alnost anywhere in or near Boutheastern Alask. It is gratifying to see these services exponding.

\section{RRMARKS ON THE BARTTRR PRCGRAM}

In looktas through the record of Congressional hearings on the Department of Interlor's proposed long-range minerals program, we were interested in seelng Senator Malone's remarks on the berter program. We repeat them here for others who will also be interested. 
"It 18 difficult to fathom the mental processes of those who advocate trading the surplus agricultural products of this country for forelgn minerals with the claim it will stimulate the domestice production of minerals.

"The agricultural surpluses have been taken of the domestic market at great cost to the American taxpayer, several billions of dollars a year in fact. When these agricultural products are sent abroad they obviously mast be disposed of at a luss. It is impossible to see how it can be otherwlse. It $1 \mathrm{~s}$ also true that as high a price is placed on the forelgn minerals as the trafelc will bear. To this extent there is an artificiel price placed on these rainerals. But each barter deal is a separate transaction. There is no continulty or principle 1nvolved.

"The only certainty 18 that the damestic ninerals industry $w 111$ be destroyed.

"Many of the forelgn mineral projects have been financed by loans or forelgn ald programs for which the American ta:payer has a.lso paid. It is impossible to see how taking the foreign minerals which have been stimuleted to excess production is golng to belp the domestic miver to stay in business at all. In the first place there is no foreign country from which minerals are recelved where the wages exceed much more than 10 percent of our own and in meny cases it is a good deal less.

"Are the one-worlders in the State Department and other departwents in the Government suggesting that we lower the standard of living in this country in order to be on a competitive level with forelgn countries? Heve they ever taken the trouble to find out who the people are in this country who pey the taxes in order to support these grandiose forelgn Bcherres?

"I have never seen nor has this cormittee ever been given a clearcut example of a single barter deal. No representative fron the Department of Agriculture or the ICA has ever been able to explain in understandable language how barter works otter then to say that the deals are handled by brokers in this country and abroed.

"It 18 a well-known fact that brokers get their commission. Everybody along the line makes a profit, except the Anerican taxpayer."

\section{MTIE SAFETY}

The National Sefety Council is sponsoring a National Campeign to Prevent Injuries fram Roof Falls, beglnning July 1, 1957 and termluating June 30, 2958. The campelgn's goel is a $50 \%$ reduction in infuries and deaths from roof falls during the year. The TDM will supply brochures.to all coal mines in the Territory and w1ll be glad to cooperate with all parties or operators interested in participating in this program. 
E. AIND M. J. METAL MARKET PRICES

\begin{tabular}{|c|c|c|c|}
\hline & $\begin{array}{l}\text { June } 20 \\
1957\end{array}$ & $\begin{array}{l}\text { Month } \\
\text { Ago }\end{array}$ & $\begin{array}{l}\text { Year } \\
\text { Ago } \\
\end{array}$ \\
\hline $\begin{array}{l}\text { Copper, per lb. } \\
\text { Lead, per lb. } \\
\text { Zinc, per lb. } \\
\text { T1n, per lb. } \\
\text { Qulcksilver, per flask } \\
\text { Silver, forelgn, New York } \\
\text { S1lver, domegt1c, per oz. } \\
\text { Nickel, per lb. } \\
\text { Molybdenum, per Ib., in con. } \\
\text { Platinum, per oz. } \\
\text { *Iungsten ore, per unit } \\
\text { Titanium ore (Ilnenite) }\end{array}$ & $\begin{array}{c}30.7 \phi \\
14 \phi \\
10-3 . / 2 \phi \\
98.2 \phi \\
\$ 255-257 \\
90.2 \phi \\
90-1 / 2 \phi \\
74 \phi \\
\$ 3.18 \\
\$ 89-95 \\
\$ 55.00\end{array}$ & $\begin{array}{l}31.2 \phi \\
156 \\
11-1 / 2 \phi \\
98.5 \phi \\
\$ 255-257 \\
90-7 / 8 \phi \\
90-1 / 2 \phi \\
74 \phi \\
\$ 1.18 \\
\$ 90-95 \\
\$ 55.00\end{array}$ & $\begin{array}{c}45.0 \phi \\
16 \phi \\
13-1 / 2 \phi \\
94.8 \phi \\
\$ 257-259 \\
90.3 \phi \\
90-1 / 2 \phi \\
64-1 / 2 \phi \\
\$ 1.10 \\
\$ 103-110 \\
\$ 33.00\end{array}$ \\
\hline * & $\begin{array}{l}\$ 26.25-30.00 \\
.0) \\
\$ 115.00\end{array}$ & $\$ 26.25-30.00$ & $\$ 20.00$ \\
\hline
\end{tabular}

*GSA tungeten purchasing presently ouspended. Foreign import price \$19.25

* *GSA guaranteed stoclpple price. Not quoted by $2 . \&$ M. J. 